\title{
CERONE AS HISTORIAN
}

Enrique Alberto ARIAS

\begin{abstract}
In 1997, Professor Robert M. Stevenson wrote an article entitled "Pedro Cerone (1566-1625): Impostor or Defender of the Faith." Professor Stevenson ends his provocative article, which includes a brilliant analysis of the reception history of El Melopeo y Maestro (Naples, 1613) as well as a comprehensive biography of its author, with an invitation to further research on various aspects of El Melopeo. In response to this invitation, the present article seeks to further our understanding of this frequently misunderstood treatise. I have often asked myself this essential question: if Cerone had never written $E l$ Melopeo or if every copy of this treatise had been lost, would our understanding of the music and theory of the $16^{\text {th }}$ century be different? I think the answer is obvious.
\end{abstract}

\section{Resumen}

En 1997, el profesor Robert Stevenson escribió el artículo titulado "Pedro Cerone (1566-1625): Impostor or Defender of the Faith"'. El profesor Stevenson finaliza su provocativo artículo (que incluye un brillante análisis de la historia de la recepción de El Melopeo y Maestro, Nápoles, 1613, así como una biografía completa de su autor) con una invitación a continuar con las investigaciones sobre diversos aspectos de El Melopeo. En respuesta a su invitación, el presente artículo persigue llegar más allá en nuestra comprensión del tratado, a menudo malinterpretado. A menudo me he planteado una cuestión esencial: si Cerone no hubiera escrito nunca El Melopeo, o si todas las copias de su tratado se hubieran perdido, ¿habría sido diferente nuestra comprensión de la música y la teoría del siglo XVI? Creo que la respuesta es obvia.

\section{In Defense of Cerone}

Warren Dwight Allen's Philosophies of Music History: A Study of General Histories of Music, 1600-1960 brilliantly summarizes Pedro Cerone's accomplishments as theorist and historian. Allen notes that three major musical writers of the early $17^{\text {th }}$ century presented comprehensive views of the music of their day: Michael Praetorius, Marin Mersenne, and Pedro Cerone. Allen than contrasts Cerone with Seth Calvisius (1536-1615), the first theorist to develop a specifically historical approach:

His interests were primarily ethical and technical. Like Calvisius, he was interested in precepts, but not the nova et facillima-rather the good old conservative precepts of discipline, temperance, and virtue. At the beginning of the work the term Historia has nothing in common

1. Robert M. Stevenson, Inter-American Music Review 16 (1997): 1-27.

Anuario Musical, 58 (2003) 
with the sense in which Calvisius used the term. He admits the necessity of dwelling upon digressions, Historias, fabulas y sentencias, but shows no intention of writing a history. For Cerone there is no connection whatever between the ancient music and modern music since Guido. There is no persistence of Hebrew tradition as for Praetorius, and no genealogical chain ab initio mundi ad praesens tempus as for Calvisius. ${ }^{2}$

After examining Cerone's views on the origins and purposes of music, Allen neatly sums up Cerone's position, "In other words, music is divided into fixed categories that can only be compared, not connected."3

Jon W. Finson, and others have noted that musicology in its modern form begins with the great sytematic treatises of the earlier 17 $7^{\text {th }}$ century: Cerone's El Melopeo y Maestro (1612), Michael Praetorius's De Organographia (1618), Marin Mersenne's Harmonie Universelle (163536), and Athanasius Kircher's Musurgia Universalis (1650). These treatises summarize the musical thought of their day and provide information about the history and development of musical instruments.

Finson writes: "Vocal music is still the predominant art music in these treatises, but the new organologies reflect an acceptance of instrumental music without which the present state of the orchestra would be unthinkable."4 Cerone's El Melopeo was the first of these great encyclopedic works and indeed set the tone for the encyclopedic musical treatises of the $17^{\text {th }}$ century. El Melopeo may indeed have influenced Mersenne's Harmonie Universelle, for, as we shall see later in the article, he was aware of Cerone's treatise.

\section{Background}

The length and complexity of El Melopeo y Maestro (Naples, 1613) have disturbed many readers. Cerone's reputation as an author who delights in bizarre excess has further impeded our understanding of $\mathrm{El} \mathrm{Melopeo,} \mathrm{as} \mathrm{has} \mathrm{the} \mathrm{increasing} \mathrm{evidence} \mathrm{that} \mathrm{Cerone} \mathrm{paraphrased} \mathrm{the}$ writings of other theorists - a common practice in theoretic discourse in the Middle Ages and Renaissance. ${ }^{5}$ Yet the value of this treatise lies not in its originality but in the frequent expansion and explanation of other theorists' concepts.

Cerone himself describes the circumstances that inspired his love of music:

For many days I decided to write on the Art of Music, as I had begun to do in Bergamo (a city in Lombardy, and my fatherland). I really had done little on the project, but in the same year 1962), 14.

2. Warren Dwight Allen, Philosophies of Music History: A Study of General Histories of Music (New York: Dover,

3. Allen, 14. Allen does not see Cerone so much as an historian as a theorist.

4. Jon. W. Finson, "Musicology and the Rise of the Modern Orchestra," in The Orchestra: Origins and Transformations (New York: Billboard Books, 2000), 433-34.

5. Ruth Hannas, "Cerone, Philosopher and Teacher," The Musical Quarterly 21 (1935): 408-22. Hannas makes clear that at no time Cerone pretended to be an innovator (p. 410). In general, Hannas emphasizes Cerone's contributions rather than his "plagiarisms." This classic article has influenced the present study. 
I left my former employment and went to Sardinia to work in the major church of Oristan, with the plan to go to Spain afterward, which I accomplished in the year $1592 .{ }^{6}$

We are certain neither of the order of creation nor the date of the completion of the text. Francisco García, in his dissertation on El Melopeo, suggests 1608 as the year of termination, but others have argued for other dates. ${ }^{7}$ Several passages suggest the chronolgy. As we shall see later, Cerone notes that Mateo Romero was Maestro di Capilla to Philip III. ${ }^{8}$ Romero worked for Philip III's Flemish chapel in Madrid from 1598 to 1634; thus this passage was written after (perhaps even well after) 1598. In general, Cerone probably began sketching El Melopeo in the later 1590s, but completed this huge work around 1607, or at a time when Cerone's career in Naples was at its peak. Professor Stevenson points out it took Cerone five years, 1608-13, to get El Melopeo through publication. ${ }^{9}$ Cerone probably completed the treatise as early as 1607 in order to present his magnum opus to his publisher. Accordingly, Cerone wrote El Melopeo in less than ten years, though he probably conceived this treatise and began gathering materials for it much earlier.

\section{Cerone's Biography}

Although Professor Stevenson presents a comprehensive biography of Cerone in the article mentioned at the outset, I offer the following capsule biography to put my subsequent discussion into perspective.

Born in Bergamo, Italy around 1566, Cerone early became aware of Spanish music through his study with Juan Verio, chapelmaster to Margaret of Austria. In 1592, his search for better teachers led him to Sardinia (at this time under Spanish control), where he was influenced by Anthoine de Loch of the Calgiari Cathedral in southern Sardinia.

I also have known all of this by experience, particularly for having had a close friendship with Juan Verio of the Flemish nation and chapelmaster for Margaret of Austria, who is in heaven. I studied with him (Juan Verio) and requested relief from my doubts during the four years spent in the ducal city of Abruzo in the service of the archbishop. ${ }^{10}$

6. Muchos dias ha, me determine de escriuir alguna cosa sobre el Arte de la Musica, como comence hazerlo à Bergamo (ciudad de Lombardia, y mi patria) mas ha de quinze años: aunque fue tampoco lo que ecriui entonces, que puedo dezir (y con mucha verdad) no fue nada; pues el mesmo año dexe la empresa y me fuy à Cerdeña al seruicio de la Yglesia mayor de Oristan, con determinacion de me passar despues à España; como lo cumpli el año del mil y quingentos, y noventa dos., p. 1 .

7. Francisco García, "Pietro Cerone's El melopeo y maestro: A Synthesis of Sixteenth-Century Music Theory," (Northwestern University: Ph.D., 1978), 18.

8. See footnote 24 . It is probable that Romero was already well established in his position at the time of Cerone's writing El Melopeo. I would guess that he had already been working for the king for at least a year or two-which pushes the date of the writing of El Melopeo into the early $17^{\text {th }}$ century.

9. Stevenson, 5 and 7.

10. Yo tambien he sabido por experiencia todo esto, particularmente por auer tenido muy estrecha amistad con Iuan Verio de nacion Flamengo y Maestro de Capilla, que à sido de Madama Margarita de Austria, que esta en el cielo. Con quien en el tiempo de quatro años, que me tratuue en Ciuitaducal de Abruzo en seruicio de la Capilla del Obispado, conseria mis estudios; y à quien pedia parecer en mis dudas. p. 92. 
In 1593, Cerone, by this time an admirer of Spanish culture and history, made a pilgrimage to Santiago de Compostela, stopping off at Tarragona. According to his own account, Cerone then traveled widely and studied as much Spanish music and theory as possible.

At this same time, I traveled through the diverse regions of these fortunate kingdoms of Spain. As men who are anxious to see everything do not rest, and the effort expended does not seem effort, when I arrived at a city, I did not rest until I spoke with the masters of music. Having gained much or little, I went to the book stores to see treatises on the art of music. I read them and took from them their flower and substance-all of which serves in the present treatise. ${ }^{11}$

In 1603, Cerone left Spain to become a priest and singer at the church of SS. Annunziata at Naples. Although Cerone researched El Melopeo during his Spanish years, it was published in Naples in 1613, dedicated to Philip III. Naples was at that time under Spanish dominion and Spanish was commonly spoken. That Cerone wrote in Spanish rather than in his native Italian demonstrates his apparent desire to address the Spanish Empire as his primary audience.

Cerone was impressed by the rich musical life in Naples and contrasted it with the relatively bleak cultural landscape of Spain. He became passionately interested in improving musical education in the Spanish Empire-the driving purpose for the writing of El Melopeo. The following quotation demonstrates his awareness of the excellence of Italian musical pedagogy, but it also invites the Spanish to adopt similar approaches:

Until recently I did not perfectly understand why one finds more professors of Music in Italy than in Spain. Nonetheless, it seems there are five principal reasons. The first is the greater diligence of the teachers, the second is the tolerance and patience of the student, the third is the particular affinity the Italian nation has to music, the fourth is the many opportunities to come into contact with music, the fifth and last is the wish the Italians have to learn something new every day. ${ }^{12}$

\section{Cerone's Sources}

As suggested earlier, Cerone derived his historical approach from Renaissance sources, of which the following are some of the principal:

11. A esto mesmo sin de saber, he ydo peregrinando por diuersas tierras destos dichosos Reynos de España; y como quiera que los hombres desseosos de ver muchas cosas no descansen descansando, y como los trabajos que se toman de voluntad no sean trabajos si no gustos, en llègando que llegaua en una ciudad no curaua descansar; antes, despues de auer praticado con los Maestros que hauia en ella, y deprendido de todos poco ò mucho, yua por las librerias à buscar las artes de Musica, y las que ha haua leyua y secaua dellas la flor y la sustancia; de lo qual me siruo agora en este presente tractado. p. 92.

12. Hasta agora no acabo de entender, porque causa se hallan mas professores de Musica en Italia que en España: con todo esso digo me parece que es por cinco principales causas. La primera, por la mayor diligẽcia de los Maestros: la segunda, por el sufrimiento y paciencia del dicipulo: la tercera, por vna particular afficion, que la nacion Italiana tiene à la Musica: la quarta por las muchas comodidades que tienen para deprehenderla: la quinta y ultima por un desseo natural que los Italianos tienen de saber cadadia mas de lo que saben... p. 148. 
Bartolomeo Ramos de Pareia, Musica Practica (1482)

Franchinus Gaffurius, Practica Musicae (1496)

Bonaventura da Brescia, Brevis Collectio Artis Musicae (1497)

Gregor Reisch, Margarita Philosophica (1503)

Andreas Ornithoparchus, Musicae Activae Micrologus (1517)

Pietro Aron, Il Toscanello en Musica (1523)

Giovanni Maria Lanfranco, Scintille di Musica (1533)

Heinrich Glarean, Dodecachordon (1547)

Juan Bermudo, Declaración de Instrumentos Musicales (1555)

Nicola Vicentino, L'antica Musica Ridotta alla Moderna Prattica (1555)

Gioseffo Zarlino, Le Institutioni Harmoniche (1558)

Frater Illuminato Bresciano Aiguino, La Illuminata de Tutti i Toni di Canto Fermo (1562)

Tomás de Sancta María, Libro llamado Arte de Tañer Fantasía (1565)

Gaspar Stoquerus, De Musica Verbali Libri Duo (c. 1570)

Martin de Tapia, Vergel de Música (1570)

Francisco de Salinas, De Musica Libri Septem (1577)

Pietro Pontio, Ragionamento di Musica (1588)

Francisco de Montanos, Arte de Música (1592)

Pietro Pontio, Dialogo (1595)

In addition, Cerone praised Boethius as the principal theorist and cited Guido d'Arezzo's Micrologus (c. 1025) and Marchettus of Padua's writings (Lucidarium [c. 1318] and Pomerium [1326]). Cerone also quoted a wide range of classical authorities to support general philosophic concepts. Almost every chapter of El Melopeo ends with a series of quotations from classical literature to support the points just made, evidencing the influence of the Italian humanist movement. Pietro Pontio's two treatises, appearing as El Melopeo was at least in the planning stages, influenced Cerone deeply and served as a source for many of his ideas. Beyond paraphrasing specific passages, Cerone echoed the methodologies of the theorists listed above, but Zarlino was always the theorist Cerone revered the most highly.

Ramos de Pareia, whose Musica Practica (1482) caused a stir because of its critique of the Guidonian hexachord system, is mentioned, thus suggesting that Cerone was aware of this innovative treatise. ${ }^{13}$ More specifically, Cerone was influenced by particular features of these treatises. For example, Lanfranco's Scintille di Musica's clearly pedagogical and pious intent but also its division of composers into ancient and modern impacted El Melopeo. Both Cerone and Lanfranco begin their lists of "ancient" composers with Josquin. Lanfranco writes that "modern" composers start with Willaert, while Cerone names such Spaniards as Morales and Ortiz as the first moderns. Following a common practice, both writers view "ancient" music as that from the early $16^{\text {th }}$ century, while "modern" music is the music of the time when they themselves were

13. He is mentioned as "Españolo" on p. 284. 
young. Martin de Tapia's conservative tone must have appealed to Cerone. In addition, Tapia's list of preferred authors influenced Cerone as did his strongly conventional organization of the treatise.

Frank García sums up Cerone's approach to his sources:

Cerone's method of using acknowledges material however suggests that he made a conscious effort to disguise his borrowings. Moreover, considering the extent of Cerone's preponderant reliance on Montanos, Sancta María, Tapia, Zarlino, Lanfranco, Ponzio, et al.. the number of times that Cerone acknowledges his sources in El Melopeo is insignificant by any standards. ${ }^{14}$

We, however, cannot expect Cerone to follow the procedures of modern academic practice; and his views, no matter how often derived, are worthy of comment.

\section{Cerone the Historian}

Cerone wrote two crucial chapters, numbers 32 and 33 of the first book of the monumental El Melopeo y Maestro, that delineate his attitude toward his musical contemporaries and demonstrate his historical approach. While most of the ideas are commonplaces, Cerone's ordering and emphasis are occasionally his own. Chapters 32 and 33 of the first book and related statements in Book II of El Melopeo will be the subject of the present article.

Cerone, echoing Boethius and most Medieval and Renaissance theorists, searches for the origins of music. Various mythological inventors of music are considered, coming from different peoples and times:

And to finish this discussion we say that in different times and different places (music is ascribed to various inventors): Tubal before the flood, Mercury and the rest after the flood, Orpheus and Amphion among the Gentiles, Pythagoras among the Greeks, Moses among the Hebrews, Boethius among the Latins, and so it goes. ${ }^{15}$

However, Cerone doubts who was the inventor of music:

It is not known who was the inventor of our music, or, to speak truthfully, I do not know. I know that it is older than 150 years and that it is much more ancient than the disciple of Zarlino states in the third book of his treatise on music. Who might be the inventor of our music can be gathered from Guido of Arezzo's Micrologus, where, in Chapter 18, he speaks of Diaphony. Guido lived during the pontificate of Pope Benedict VIII, which began in the year of Our Lord 1018, which is more than 590 years earlier than the present date. And I can speak affirmatively that it

14. García, 12.

15. Y para remate de todo esto diremos, que la Musica no tuuo vn sol inuentor, mas muchos inuentores, en diuersos tiempos y en differentes naciones. Como Thubal antes del diluuio; Mercurio y todos los demas, despues del diluuio: pero Orpheo y Amphion entre los Gentiles Idolatras, Pythagoras entre los Griegos, Moysen acerca los Hebreos, Boecio entre los Latinos, y assi de los demas. pp. 226-7. 
may be older and may be 940 years ago. Venerable Bede lived during the pontificate of the Canon of Tracia in the year of Our Lord 673. Bede affirms in his time that music consisted of "concentu, discantu cantu atque organis," or of a concentus of diverse song with organ and instruments. ${ }^{16}$

\section{This passage mirrors Martin de Tapia:}

Who might be the inventor of it (music) is doubtful because of its antiquity and dignity. Because of its antiquity, the inventor is not certain. For its dignity and excellence, each one of these musicians (if it were posible) would like to attribute it to himself. ${ }^{17}$

\section{Ultimately, Cerone suggests that music is derived from nature-a view later propounded} by Rousseau.

One cannot contradict that nature comes before art or that the sound that arises from a man's mouth or a little bird is legitimate and natural, more so than the sounds that come from instruments, which are complex, adulterated, and artificial. From this it can be said that instruments were created only to imitate natural voices. ${ }^{18}$

Cerone divides music into two types: older music, which is monophonic, and more recent music, which is polyphonic. Ancient music, however, was nobler and more serious:

The ancients in their music sang material and subjects very different from those found in modern song, for they sang of grave, learned matters, composed with much elegance, and a variety of verses. ${ }^{19}$

Cerone notes that the music of the moderns does not have the same effect as that of the ancients:

16. Quien aya sido el inuentor dessa nuestra Musica, no se sabe; ò alomenos digo con verdad, que yo no lo se. Bien se que muchos años ha que esta en vso y que es mucho mas antigua de lo que dize el discipulo de Zarlino, en el 3.del terc. lib de su Mus. el qual quiere no sean mas de 150. años que se entroduxo. Que sea mas antigua, se puede sacar de lo escriue Guido Aretino en el lib. de Mus. llamado Micrologo, en el cap. 18. adonde habla de la Diaphonia. El qual viuia en el Pontificado de Papa Benito VIII. el año de nuestra saluacion de 1018, adonde ya son passados mas 590 años. Antes soy por dezir affirmatiuamente que no es tan nueua, que no passen 940. años: porque siendo Summo Pontifice Canon de Tracia, en los años del Señor 673, viuia tambien el Venerable Beda Ingles, el qual confirma que en su tiempo se exercitaua la Musica, Concentu, discantu, cantu atque Organis. Es à sauer con concento, con canto diuerso, y con Organos ò instrumentos. pp. 2278. Actually, Guido of Arezzo lived during the pontificate of John XIX. The reference to Bede is to the Venerable Bede (673-735), whose principal work was the Ecclesiastical History of the English People (731). The reference is to Pope Conon (686-87). There were 14 popes during Bede's lifetime, the last of which, St. Gregory III, reigned 731-41.The reference to the student of Salinas is to Gaspar Stoquerus, who was a student of Salinas at Salamanca and may have helped this blind theorist transcribe the Musica Libri Septem (1577). See De musica libri duo: Two Books on Verbal Music, ed. Albert C. Rotola (Lincoln: University of Nebraska Press, 1988).

17. Quien sea el inuentor de ella, algunos lo ponen in duda por la antiguedad, y dignidad, que tiene. Por la antiguedad, no ay certidumbre del inuentor, y por la dignidad y excelencia, cada uno de los musicos (si posible fuesse) la quieria atribuyr a si. Martín de Tapia, Vergel de Música (1570), f. 37r-37v.

18. No se puede contradezir que la naturaleza no sea primero que el arte, y assi el sonido que sale de la boca del hombre ò de auecilla, es legitimo y natural; mas el que sale de los instrumentos, es bordo, espurio y artificial: y siendo assi, es menester dezir que los instrumentos an sido formados, solo para imitar las bozes naturales. p. 243.

19. Los antiguos en sus Musicas cantauan materias y subjectos muy differentes de los contienen los cantares modernos; porque recitauan cosas graues, doctas, y compuestas con mucha elegancia, en varios generos de versos. p. 240 . 
It seems to me that the situation is thus. Our music is created of various voices that disturb the natural effect of the intervals and consonant numbers, and obscure the meaning of the words. Also many moderns lack the knowledge of the tones. ${ }^{20}$

Yet, ironically, Cerone elsewhere implies that the music of the moderns is richer than that of antiquity:

It is necessary to note that the music of the ancients did not employ such a diversity of instruments (apart from the music used in comedies or for exercises). Nor were their ensembles composed of such parts nor did their music use such a variety of voices as is now the practice. ${ }^{21}$

Cerone provides specifics, reflecting Boethius, on the history of the three genera:

Of these three genera, the diatonic is the most ancient... much later the chromatic genus was discovered by Timotheus of Milesia... in the hundred eleventh Olympiad, which is to say about 338 years before the coming of Our Savior. Many years later another musican came to the world who had the name of Olympus, who invented the enharmonic genus, and this was about 218 years before our salvation. ${ }^{22}$

Cerone also writes of the history of instruments, including tuning, diagrams, and specific performance problems. This methodology anticipates Praetorius' Syntagma Musicum (1614-20) and Marin Mersenne's Harmonie Universelle (1636). This list of instruments includes the Lira da braccio, which, as Michael Zywietz points out, is the last time it is mentioned in Renaissance theoretic discourse. ${ }^{23}$. Once more, a quasi-historic approach prevails in that origins, comparisons, and important persons are mentioned. Because of this interest in the history of musical instruments, Cerone considers the inventors of instruments, including the organ:

And so much can be said about old organs. The moderns invented another kind of organ, which is more complex, sweet, and, in many ways, more evolved and finished. It is more than 453 years that our organs have been used in the Church of God. ${ }^{24}$

20. Lo que me parece proceder, porque la Musica nuestra es compuesta, es à sauer consta de diuersas bozes, con que se viene à perturbar el effecto natural de los interualos y numeros consonantes, y à oscurecer la inteligencia de la palabra; y tambien porque muchos modernos carecen del verdadero conocimiento de los Tonos. p. 235.

21. Es menester aduertir que la Musica de los antiguos no era con tantas diuersidades de instrumentos (dexando à parte la que vsuan en las comedias y en sus exercicios). Ni tampoco sus concentos eran compuestos de tantas partes, ni con tanta variedad de bozes hazian su Musica, como agora se haze. p. 239.

22. Destos tres Generos el Diatonico es el mas antiguo mucho tiempo despues fue hallado el Chromatico de Timotheo Milessio... en la centesima onzena Olympiade, conuien à saber cerca los años 338 antes de la venida de Nuestro Salvador... Muchos años depues vino al mundo otro Musico que tenia nombre Olimpo, el qual inuentò el Genero Enharmonico, y fue cerca à 218. años antes del año de Nuestra Saluacion... p. 250.

23. Michael Zywietz, "Cerone" in Die Musik in Geschichte und Gegenwart, Zweite, neuarbeitete Ausgabe, Personenteil, v. 4, col. 564.

24. ... Destos organos, otros mas modernos, inuentaron el nuestro Organo, que es mucho mas artificioso, mas saue, y en muchas cosas mas copioso, y mas acabado. Que sean mas de 453 años, que los Organos nuestros se usan en la Yglesia de Dios... p. 245. 
Cerone also documents the history of notation in Chapter 62 of Book 2 "De las señales $y$ cifras que usaron los primeros Musicos en lugar de figures ò notas" (Of the signs and cifers that the first musicians used instead of figures and notes). He points out, using Boethius' $D e$ Musica as his source, that ancient musicians used certain indications over the text to imply pitch:

I note that Severino Romano (Boethius) in a chapter of his fourth book states that the ancients, when they wanted to notate music did not have the notation, clefs, or instruments that we have, neither did they indicate all the names of the strings that music employed. Instead, they used certain signs they placed over the verses they had to sing. ${ }^{25}$

Later others began to use alphabetical letters between the spaces of letters (which, occurs, of course, during the period of Guido of Arezzo or the $11^{\text {th }}$ century) ${ }^{26}$ Cerone supports this with a comparative musical example of notation: A lo antiguo. Esta es agora (In the ancient manner. As it is now).

Chapter 63 continues this discussion of notation, but as it can be applied to mensural polyphony (the previous chapter had only dealt essentially with non-mensural monody and its evolution into polyphony). This chapter is entitled "De las primeras musicales, que nuestros antepassados usauan en Canto de Organo" (Of the first musical [signs] that our predecessors used in rhythmic song). Using Gaffurius' Practica Musicae (1496) as his source, Cerone refers to Greek notation. The term brevis is used because it is the shortest in time. ${ }^{27}$ A diagram illustrates the names, forms, and values of the notation, again betraying Cerone's wish to show historical comparisons.

Other figures were quickly added: "Musicians used these to create vocal compositions around the year of our salvation 1124 that lasted, as we shall say later, for over two hundred years. ${ }^{28}$ The early $12^{\text {th }}$ century is the century after Guido and indeed is the period of melismatic organum when mensural notation evolves considerably.

In a crucial statement, Cerone writes:

For as Franquino states in the chapter De diminutioribus figuris, Prosdocimus called them and formed them in one way, Johannes Tinctoris in another, Philippus de Caserta in yet another, Anselm Parmense in another, and many others each in their own way, and finally yet in another Juan de Muris Frances, who, around the year of our salvation 1352, invented the eight figures

25. Para principio desto, digo que cuenta Seuerino Romano en su lib. 4 al Cap. iij. que los antiguos quando hauian de puntar alguna Musica, no tenian los puntos, ni las Claues, ni instrumentos que nosotros tenemos; si no por no poner todos los nombres de las cuerdas por las quales la tal Musica andaua, usauan ciertas señales sobre los versos que hauian de cantar. p. 294.

26. Despues otros Musicos (dexada esta manera de puntar) comensaron usar las letras alphabeticas, texidas entre las lineas largas... p. 295. tiempo... p. 296.

27. A la primera, usando palabras que todos entiendan llamaron Brevis, porque era la mas breve en valor de

28. Con estas pues formauan sus Cantos los Musicos que fueron cerca de los años de nuestra Saluacion 1124, y duraron por mas de dozcientos años, como luego diremos. p. 298. 
commonly used by us. Practical musicians, singers, and composers used them in art, because they are elegant in form and easy to write. ${ }^{29}$

As the quotation indicates, this information is derived from Gaffurius' Practica Musicae, where one reads the following in Chapter four of Book two entitled "The Shorter Notes": "There are some who have passed on a tradition of different forms for these notes, including Franco, Philip of Caserta, and even Johannes de Muris and Anselm of Padua (sic) in the third session of his Musica" ${ }^{30}$ Prosdocimus and Tinctoris are mentioned earlier in the same section, but the date 1352 is not given.

The rubrics for this section also tell us that Cerone used Glareanus and Salinas for this information as well. Gaffurius, however, was Cerone's principal source for early theory and his thorough discussions of both the practical and theoretic aspects of music must have provided a model for El Melopeo. Cerone must also have been impressed with Gaffurius' command of humanistic sources and compositional practice (Gaffurius was a composer himself).

Cerone (relying on Gaffurius) does not list the theorists in correct chronological order in the quotation presented above (Tinctoris, of course, was active after Johannes de Muris). The choice of the year 1352 is striking. It clearly related to the activities of Johannes de Muris, who died after 1344, but whose seminal treatise Libellus Cantus Mensurabilis is dated c. 1340. It is this treatise that codifies later medieval mensural notation, the notational system that Cerone (again through Gaffurius) here relates.

\section{Cerone on Theorists}

As I noted previously, Cerone wrote two chapters in Book I about theory and composition during the $16^{\text {th }}$ century. These chapters were intended to aid the novice chapelmaster working in the Spanish Empire find appropriate models of theory and composition. However, the following quotations also reveal Cerone's personal method of study.

The first chapter is entitled: "That it is necessary for maestros that they read diverse treatises on the art of music and that they study many works on practice." The reading of Francisco de Montanos and Francisco de Salinas, Spain's leading theorists of the $16^{\text {th }}$ century, should inspire further research:

29. Porque, como dize Franquino en el Cap. De diminutioribus figuris; Prodocismo (sic) las llamaua y formaua de una manera, Iuan Tinctoris de otra manera, Phisiphus (sic) de Caserta de otra, Anselmo Parmense de otra, otros muchos de otras, y finalmente de otra Iuan de Muris Frances, el qual cerca los años de nuestra Sal. De MCCCLII inuentò las nuestras ocho figuras; las quales por ser mas galanes en la forma y mas faciles de hazer, luego las Musicos praticos, Cantores, y escritores las pusieron en uso y arte. p. 300.

30. The Practica musicae of Franchinus Gaffurius, Translated and edited with musical transcriptions by Irwin Young (Madison: The University of Wisconsin Press, 1961), 77-8. Anselm is Giorgio Anselmi (c. 1386-c. 1443), a theorist often cited by Gaffurius. He is usually called Anselm of Parma not Padua. 
He who wishes to know this profession perfectly should not be content with the Arte de Música practica of the famous Montanos nor the speculative treatise of the most learned Salinas, of whose works the Spanish rightly have a high opinion. But, if not keeping too close a watch on the pocketbook, one should use much diligence in gathering all the treatises that are published, and to make use of all a bit or much. ${ }^{31}$

Boethius is the most important theorist:

Who does not know that the divine Boethius, the Roman, who was not afraid of the studies of his predecessors and elders, in addition to the acuteness of his judicious ear (speaking only of speculative studies) holds the highest place in music among the Latins?

His place has not been taken by Guido of Arezzo, Franchinus Gaffurius, Andreas Ornithoparcus, not even Heinrich Glarean nor Gioseffo Zarlino, nor the rest, both greater and lesser, whose names I do not plan to recite. ${ }^{32}$

But Cerone highlights which Renaissance theorists influenced El Melopeo. (In the following list Venturina refers to Bonaventura da Brescia, while Toscanela refers to Pietro Aron's Il Toscanelo.)

Nonetheless, one should not disdain to read sometimes some modern treatise on Music, as is my custom. Sometimes I take into my hands Venturina, a Toscanela, a Boethius, a Margarita philosophiae; other times I read a Lanfranco, an Aiguino, a Salinas, a Zarlino, or some other treatise to examine a speculative matter or know some antiquity. ${ }^{33}$

Cerone wrote El Melopeo within an advanced theoretic tradition at the Neapolitan court. Johannes Tinctoris worked for the court of Ferdinand I, beginning about 1472, and it was at Naples that he conceived the Proportionale Musices (c. 1476). Franchinus Gaffurius became acquainted with Tinctoris in 1478-80, and his Opus Armonice Discipline was published in Naples in 1480 , when Gaffurius had reached the zenith of his reputation. Francisco de Salinas was organist at the viceregal chapel at Naples between 1553 and 1558, where he conceived his influential De Musica Libri Septem (1577). At this time, the viceregal chapel was directed by Diego Ortiz, who had arrived in Naples by 1553 and was chapelmaster at the viceroy's chapel

31. El que dessea saber acabadamente esta profession, no se contenta solo con tener la arte de Musica pratica del famoso Montanos, ni la especulatiua del doctissimo Salinas, de cuyas obras con razon los Españoles tienen grande opinion: mas, sin perdonar à dineros, trabaja usando mucha diligencia en juntar todas las que imprimidas estan; y de todas poco ò mucho aprouecha. p. 87.

32. Quien no sabe, $\overline{\mathrm{q}}$ el diuin Boecio Romano, no se ãspantò de los estudios de sus predecessores y mayores, antes co la agudeza de su ojo judicioso (solo de la especulatiua hablado) mirò si justo y tan alto, que en la Musica entre los Latinos el primer lugar tiene? Mas no por esso ha tomado el lugar à Guido Aretino, ni à Franquino Gaffuro, ni à Andres Ornythoparcho, ni à Henrique Glareano, ni à Ioseph Zarlino, ni tampoco à los demas, ò mayores, ò menores que sean de los ya dichos, que regoladamente y no entiendo recitarlos. p.1.

33. Ni por esto se desdeñen de leer auezes algun tractado de Musica moderno, y hazer como hago yo. Vnas vezes tomo en las manos vna Venturina, vn Toscanela, vn Boecio, vna Margarita philosophiae, otras vezes leo un Iuan Lafranco, vn Agiguyno, vn Salinas, vn Zarlino, ò otro tractado para ver alguna cosa de especulacio, ò para saber alguna antigualla. p. 88 . 
from 1558 to at least 1565. The Trattado de Glosas (1553), perhaps the most important of all Renaissance treatises on improvisation, was thus also written in Naples. Tinctoris is notably absent from Cerone's lists of favored authors, but Franchinus (as Cerone calls Gaffurius) and the others just mentioned are frequently emphasized in El Melopeo. Cerone thus culminates a Neapolitan theoretic tradition begun by Tinctoris.

\section{Cerone on Composers}

Cerone's discussion of composers (many of whom were his contemporaries and immediate predecessors) is strikingly perspicacious. Cerone highlights the importance of Cristóbal de Morales as the beginning of a tradition:

Although Morales during his time excelled in harmonic compositions, he also guided Palestrina, Guerrero, Ingegneri, Porta, Pietro Vinci, and the other ancients, if it is proper to call then so. Neither those that were first nor those who followed occupied the desired position that do living composers, such as Tomás Luis de Victoria, Alonso Lobo, Mateo Romero (chapelmaster to your Catholic Majesty, Philip III, may God keep you), and the like. ${ }^{34}$

Later he states that Diego Ortiz (who was active in Naples) imitated the music of Morales:

With this occasion, I do not forget the words I had in Rome with a gentleman who was a holder of a degree. I confess that Diego Ortiz was one of the best composers of his time, and worked as hard as possible to imitate Morales, of whose works all of Spain had a great opinion. ${ }^{35}$

Recent composers, however, do not obscure the great names of the past:

Certainly, the first composers who are heard of in music, were great. But more recent composers are not so many nor so new that they should obliterate our predecessors. It has been customary to consider and listen to music only of the last ten or twelve years. And many say that music has never evolved as it has recently. But this is true when anyone knows the music of Adrian Willaert, Cipriano de Rore, Pietro Vinci, Marc Antonio Ingegneri (not to mention Josquin or Gombert, as some say not to enter in the dream of the time of Pythagoras), because in no way

34. Y aunque Morales mas adelante de la señal de tantos otros traspasò en las harmonicas composiciones, con todo esto no possee sino la estancia suya, dexando la suya dellos à Prenestina, à Guerrero, al Ingignero, à Porta, à Pedro Vincio y à los demas antiguos, si antiguos es licito llamarlos. Mas ni aquellos que fueron primeros, ni estos segundos ocuparon tan por extremo la desseada señal, que con ella assi mesmo justar no pudiessen los viuientes Thomas de Victoria, Alonso Loo (sic), Mathias Romero (Maestro de Capilla de la Catholica Magestad del Rey DON PHILIPPE III. que Dios guarde) y semejantes. pp. $1-2$.

35. Con esta occasion que aqui se me ha offrecido, no estuuiendo en todo oluidado de las palabras que tuue vn dia con vn Señor Licenciado en Roma, no dexare de dezir que cõfiesso que Diego Ortiz fue el vno de los mejores Compositores de su tiempo, y que trabajò quanto fue possible para imitar à Morales, de cuyas obras toda España tiene grande opinion... p. 144. 
does this music relate to ours nor little to that that succeeded the period of Pythagoras, which is a pity. ${ }^{36}$

Cerone points out the excellence of Italian nobility and their support of music. Particularly striking is his inclusion of Gesualdo, perhaps the most radical composer of Cerone's time:

Also it is clear to many professors how good are the musical works of Don Geronimo Branchiforte, count of Camerata and those of Don Carlo Gesualdo, prince of Venosa. ${ }^{37}$

Dominique Phinot is a model composer:

I say that if Phinot had not been such an excellent composer in his day, that Palestrina would not have succeeded in our time. Phinot demonstrated in his compositions the way to attain perfection. ${ }^{38}$

Cerone narrates an amusing story about Dominique Phinot's compositional elegance:

To these discussions of older matters I wish to add one that is more recent and one that more clearly relates to our purposes. In the year of our salvation 1590, in the city of Saona, in the land of Genoa I found myself in the house of Señor Sixto Bergeroneo of the German nation. He was canon and chapelmaster of the cathedral. After having sung diverse madrigals, a young man, disciple of the chapelmaster of the principal church in Genoa wanted us to sing a long composition of his, for six voices and divided into three sections. This was done very graciously and the work was repeated several times. Now the author of the motet in three sections was very pleased. He turned with a joyful face to Señor Bergoroneo and said: "Tell on your life, Señor Sixto, how long would Señor Phinot have needed to complete such a work." At this Señor Bergeroneo was a bit quiet and with his eyes on the ground, as if deciding what he was going to say, turned and replied: "Truly, Señor, it is my understanding that he would have needed no less than three weeks for a composition so long and well developed." "Is it possible that it could be so? You should know, my Señor, that last night I sat down and did not get up from the desk until I had completed the work in the manner that you see." The other responded: "Be certain, Señor, that I believe you once, two, or three times, and would believe many yet many more times, to be pleasing. But do not be surprised if I speak in this fashion. When Señor Dominique Phinot, of blessed memory, composed a work, he concentrated all his study and placed all his energy. He studied the purpose and

36. Por cierto grandes son los primeros que se vsan oyendia en la Musica, en lo que es arte: pero no son tantos ni tan nueuos que no ayan sido vsados de los Musicos nuestros predecessores. Los que oyeron y vieron la Musica de ahora diez ò doze años; dizen que nunca estuuo tan subida la Musica, como en nuestro tiempo. De veras que el que sabe la Musica del tiempo de Adriano Vuilarth, de Cypriano de Rore, de Pedro Vincio, de Marco Antonio Ingignero (por no dezir Iusquino ni de Gombert, como dizen algunos: ni por entrar en el sueño del tiempo de Pythagoras; pues en cosa ninguna tiene que hazer aquella suya, con esta nuestra Musica) y la despues vn poco, que tiene que llorar. p. 198.

37. Assi mesmo à diuersos professores es manifesto quan buenas son las obras Musicales de D. Geronimo Branchiforte Conde de Camerata; y las de D. Carlos Gesualdo Principe de Venosa... p. 150.

38. Digo que si no fuera Domingo Phinoth (sic) eccelente Compositor en su tiempo, no huuiera succedido en nuestros dias Pedro Luys Prenestina; el qual se seruiò de la manera de componer de Phinoth, que con sus obras le mostrò el camino que hauia de tener para llegar depresto à perficion. p. 180.

\footnotetext{
Anuario Musical, 58 (2003)

(c) Consejo Superior de Investigaciones Científicas

Licencia Creative Commons 3.0 España (by-nc)
} 
scrutinized what he composed before he completed the work and had it published. And it is for this and for no other reason that he is considered one of the finest and accomplished composers of his day." 39

Francisco de Montanos likewise valued Phinot and probably influenced Cerone in his selection of this now obscure composer. Montanos at the end of the Arte de Música Theorica $y$ Practica (Valladolid, 1592) cites composers who had refined techniques.

... as Phinot does in his compositions, and Orlando (Lassus), and sometimes Morales, and often Palestrina and others of his time. ${ }^{40}$

\section{Cerone places Phinot at the head of the list of church composers:}

The practical composer that seem to me (according to my best judgment) best as models for church music are: Dominique Phinot, Jacobus Vaet, Jean Mouton, Nicolas Gombert, Simon Boyleau, Cristóbal de Morales, and Josquin. It is true in the compositions of this last composer there are good things, but mixed with so many bad that they lose sweetness, like sweet streams mixed with the sea... In madrigals it is possible to imitate Thomas Crecquillon, Adrian Willaert (especially in the collection entitles La Pecorina) and Cipriano de Rore. Of moderns it is possible to imitate Pietro Vinci, Phillipe de Monte, Orlande Lassus, Giovanni de Macque, Costanzo Porta, Vicente Ruffo, Giammateo Asola, Marc Antonio Ingegneri, Francisco Guerrero, Tomás de Victoria, Annibale Stabile, Ruger Iuvaneli, Giovanni Cavaccio, Luzzasco Luzzaschi, Lelio Bertani, Benito Pallavicino, Luca Marenzio, Giovanni Battista Mosto, Felice Anerio, Orazio Vecchi, Andrea Dragoni, Giovanni Ferreti, Girolamo Conversi, and many other that I do not count because of brevity. ${ }^{41}$

39. A este hecho antiguo y antiguas relaciones, quiero añadir otro moderno y mas à nuestro proposito, que aconteciò el año de nuestra saluacion de 1590 en la ciudad de Saona, tierra el Genouesado. Hallandome digo vna tarde en casa del Señor Sixto Bergeroneo de nacion Tudesco, Canonigo y Maestro de Capilla en la Yglesia Cathedral; adonde, despues de auerse cātado diuersos madrigales, vn mancebo dicipulo del Maestro de Capilla de la Yglesia mayor de Genoua, quiso el tambien se cantasse vna composicion suya, muy prolixa: diuidida en tres partes, y à seys bozes ordenada: lo qual se hizo muy graciosamente, repitiendola mas y mas vezes. Aora siendo enteramente complazido el author de los tres motetes, boluiose con cara muy regozijada hazia el Bergeroneo, y lo dixo; Dezidme por vida vuestra Señor Sixto, que tanto tiempo ouiera tardado el vuestro Señor Phinot à componer vn semejante canto? Aqui estuuo el Señor Bergenoreo (sic) vn poquito callado, y con los ojos puestos en el suelo, como quien reboluia en la memoria lo que hauia de responder, y tornado como sobre si, dixo. Verdaderamente Señor... por mi tengo entendido que para hazer una composicion tan copiosa y tanta largueza no huuiera tardado menos de tres semanas. Reyose entonces el desembuelto Compositor, y dixo: Es possible que estuuiesse tanto? Haueys pues de saber Señor mio, que à noche me puse à sentar, y no me leuante de la filla, que los acabe de la manera que vos lo veys. Por cietro Señor... (respondiò el otro) que yo os lo creo vna, dos, y tres vezes; y aun creerlo he muchas mas, por hazeros plazer. Pero no os admireys si yo hablo desta manera, porque quando la felice memoria del Señor Domingo Phinoth componia vna obra, ponia todo su estudio y usaua toda su industria: pensaua muy bien, estudiaua muy de proposito, y escudriñau muy por menudo lo que auia compuesto, antes que le diera fin, y que la mandarà à luz. Y assi no por otra causa que por estas, fue y es tenido por vno de los primeros y meyores Compositores de su tiempo. p. 173.

40. "... como hazé en sus obras Finot escogidamente, y Orlando, y algunas vezes Morales, y muchos Palestrina y otros de nuestros tiempos." p. 51. This occurs in a section entitles "Lugares comunes". It is striking that Phinot is cited first and that the list includes Lassus and Palestrina. This was published in 1592, before Lassus and Palestrina had died. Given the close familiarity with Montanos, Cerone clearly modeled his listing of composers on this section.

41. Los Compositores praticos que à mi parescer (saluo el mejor juyzio) se pueden imitar en cosa de yglesia son estos, Domingo Phinoth, Iacobo Vaet, Iuan Mouton, Nicolas Gomberth, Simon Boylù, Christoual de Morales, y à Iusquino. Verdad es que en las composiciones deste postrero ay cosas buenas, mas mezcladas con tantas malas, que pierden la dulçura; 
Dominique Phinot (c. 1510-c. 1555) was associated with the court at Urbino, and may have spent the latter part of his career in Lyons, France; thus he was active in the generation before Cerone. Although little is known of Phinot's biography, recent research has shown that he was probably beheaded and burned for homosexual activities. Nonetheless, Heinrich Finck's Practica Musica (1556) includes Phinot with Gombert, Crecquillon, and Clemens non Papa among the "most distinguished, excellent, and subtle composers." 42

Composers, according to Cerone, have particular talents:

Although these and the rest have composed very well, there are others who have a particular talent, one very different from the other, such as Costanzo Porta, Vincenzo Ruffo, Giammateo Asola, Francisco Guerrero, Tomás de Victoria. These have composed simple, grave, and very devout music, and what is very important, appropriate for a choir. Phillipe de Monte and Luca Marenzio have created elegant and sweet chromatic passages, or, to speak more properly, soft, lascivious, and effeminate passages. Pietro Vinci and Marc Antonio Ingegneri were the first in the area of counterpoint, that is double, retrograde, contrary, double counterpoint at the tenth, twelfth, and in all manner of counterpoint or compositions that are usual in Italy these days, and of which one could say they were the inventors... Bartolomé de Roy, Giovanni de Macque, Ruger Iuvaneli, Lelio Bertani, Giovanni Battista Mosto, Giovanni Maria Nanino, Giovanni Cavaccio, Benito Pallavicino, Felice Anerio, Annibale Stabile, Andrea Dragoni have created sweet and harmonious lines in their madrigals, and some of these composers (although few) have written for the church, particularly music for two or three choirs. Andrea Gabrieli, Claudio de Corregio, Luzzasco Luzzaschi, and Gioseffo Ascani have shown themselves excellent in Ricercares or Tientos, and other works for players of keyboard and organ in order to bring their concertos to perfection.

Geronimo Conversi, Orazio Vecchi, Giovanni Fereti, Giovanni Antonio Mortaro, Gaspar Costa, Giovanni Gastoldi have excelled in composing melodious and joyful songs, commonly called canzonettas a Napolitana and mascaradas that serve for carnival days because their subject and material is very buffoonlike, both in words and music...

He who would know many varieties and different types of counterpoint and pass the time in viewing delicious examples of music and glean good and appropriate observations regarding counterpoint, let him consider the hundred counterpoints of Don Fernando de las Infantas of Córdoba, where one will find and see things hidden from many singers, but worthy of becoming manifest to all those writing counterpoint, although not all should be imitated by good composers. Since the same plainchant is always sung, arranged in a thousand ways and repeated in a thousand places, always refreshing the memory of it (the plainchant). No less satisfactory are the counterpoints of Giovanni Maria Nanino, all composed on the same plainchant of Costanzo Festa, and always different among themselves, and all in the variety of the hundred principal

\footnotetext{
como los arrojos dulces metidos en la mar. En los madrigales se podrà imitar à Thomas de Chrequillon, Adriano Vuilaerth (particularmente los que vã impressos en la obra llamada la Pegorina) y Cypriano de Rore. Y de los modernos à Pedro Vincio, Phillipe de Monte, Orlando de Lassus, Iuan de Maque, Costancio Puerta, Vicente Ruffo, Matheo Asula, Marcantonio Ingiñero, Francisco Guerrero, Thomas de Victoria, Anibal Stabile, Ruger Iuuaneli, Iuan Cauaccio, Luzasco Luzasqui, Lelio Bertani, Benito Palauicino, Lucas Marenzio, Iuaz (sic) Baptista Mosto, Felix Anerio, Oracio Vecchi, Andres Dragoni, Iuan Fereti, Geronimo Conuersi: y à otros muchos que pro breuedad dexo de contar. p. 89.

42. Clement A. Miller, "Jerome Cardan on Gombert, Phinot, and Carpentras," The Musical Quarterly 58 (1972): 416. A quotation from Cardan is given on p. 416 regarding how Phinot died.
} 
counterpoints of the said Festa. But do not think that they are common, for they demonstrate much ingenuity and artifice as can be gathered from the few that are in print. ${ }^{43}$

Fernando de las Infantas (1534-1584), one of the principal contrapuntalists of his day, wrote the prodigious Plura modulatione genera (1579), a series of 101 canons from two to eight voices on Laudate Dominum. Costanzo Festa and Giovanni Maria Nanino (also mentioned in this quotation) both composed counterpoints over the basse dance from the late $15^{\text {th }}$ century known as La Spagna. ${ }^{44}$ This quotation also illustrates Cerone's awareness of the contrapuntal tradition of which he was a part and continued brilliantly in the final chapter of El Melopeo that is devoted to enigmatic canons (including an example by Infantas).

Some of the Italian composers mentioned in the above quotation had connections to Naples or Spain itself. Philippe da Monte, for instance, worked for the Pineli family in Naples from 1542 to 1551 . Pietro Vinci (c. 1540- c. 1584) worked at Bergamo as maestro di cappella at Santa Maria Maggiore and could accordingly been personally known by Cerone. Giovanni de Macque (c. 1550-1614) moved to Naples, where he served an organist (1594) and maestro di cappella (1599) in the Spanish viceroy's chapel. Trabaci and Mayone were his pupils, creating an experimental group of composers who contrasted with Cerone's conservatism. Mayone served as

43. Aunque todos estos y los demas han compuesto bien, todauia pero à tenido vn particular talento muy differente el vno de lo otro: por quanto Constancio Puerta, Vicente Ruffo, Matheo Asula, Francisco Guerro (sic), y Thomas de Victoria tienen compuesto vna Musica llana, graue y muy deuota: y lo que mucho importa, es que es muy chorista. Philippe de Monte y Lucas Marenzio tienen hecho muy lindos y muy suaues passos chromaticos, ò por dezirlo mas propriamente, passos moles, laciuos, y affeminados. Pedro Vincio, y Marc Antonio Ingiñero an sido los primeros que se señarlon en las diuersidades de los Contrapuntos es à sauer doblados, rebueltos, cõtrarios, à las dezena, dozena, y en todas las maneras de Contrapuntos ò composiciones, que oydia en Italian se vsan: de los quales se puede casi dezir q estos fueron los inuentores... Bartolome de Roy, Iuan de Maque, Ruger Iuuaneli, Lelio Bertani, Iuan Baptista Mosto, Iuan Maria Nanino, Iuan Cauaccio, Benito Palauicino, Felix Anerio, Anibal Stabil (sic), y Andres Dragoni han tenido lindo y harmonioso ayre en componer madrigales; y algunos dellos (aunque pocos) en cosa de yglesia, particularmente en Musica à dos y tres choros. Andres Gabrieli, Claudio de Corregio, Luzasco Luzasqui, y Ioseph Ascanii salieron eccelentissimos en los Ricercares ò Tientos: y en otras particularidades tocantes à los Tañedores de tecla y Organistas, para hazer sus conciertos en toda perficion. Geronimo Conuersi, Oracio Vecchi, Iuan Fereti, Iuan Antonio Mortaro, Gaspar Costa, Iacomo Castoldi (sic) acertaron en componer canciones ayrosas y de alegria; llamadas vulgarmente, Chanzonetas à la Napolitana; y en hazer mascaradas, las quales siruen para los dias de carnaual: por ser el subiecto y materia muy truhanesca, assi en las palabras como en la Musica...

Quien quisiere saber muchas variedades y differencias de Contrapuntos, y gastar el tiempo en ver cosas sabrosas de Musica, y de que se pueden sacar obseruaciones buenas y apropriadas para contrapuntar, vea los ciento Contrapuntos de Don Ferdinando de las Infantas Cordoues, adonde hallarà y verà cosas escondidas à muchos Cantores; dignas de ser manifiestas à todos los Contrapuntantes, mas no todas merecen ser imitadas de los buenos Compositores. Con ser siempre vn mesmo Cantollano lo que canta, guisalo de mil maneras y repitelo en mil lugares, refrescando siempre la memoria dello. No de menos satisfacion seran los contrapuntos de Iuan Maria Nanino, todos hechos de vn Cantollano y lo que es de mayor consideracion es, que obligose hazer los sobre del mesmo Cantollano de Costancio Fiesta (sic); y siempre differentes entre ellos, y en todo variados de los ciento contrapuntos principales del dicho Fiesta. No piensen por esso que sean dozenales, si no de mucho ingenio y mucho artificio, como comprehender se puede de aquellos pocos que van puestos en estampa. pp. 89-90

44. Richard J. Agee, "Costanzo Festa's Gradus ad Parnassum," Early Music History 15 (1996): 1-58. In this article Agee suggests that Festa's counterpoints were not lost, as long had been thought, but are preserved in manuscript $C$ 36 at Bologna. Festa composed 125 counterpoints (probably in the 1530s) over La Spagna, while Nanino composed 23 motets on the same cantus firmus published in 1586. These motets were included in Bologna, $\mathrm{C} 36$; thus it long was thought that this entire series was by Nanino. But Agee suggests, using stylistic evidence, that the first 125 counterpoints in $C 36$ are so different from those that follow that these indeed must be Festa's celebrated series. Festa's series influenced Infantas in the creation of his series of counterpoints, that, in turn, probably inspired Cerone's enigmatic canons at the end of $E l$ Melopeo.

102

(c) Consejo Superior de Investigaciones Científicas Licencia Creative Commons 3.0 España (by-nc)
Anuario Musical, 58 (2003)

http://anuariomusical.revistas.csic.es 
joint maestro di cappella of the Annunziata at Naples in 1595, thus working at the same church as Cerone. Mayone was also organist for the Spanish viceroy by 1602 .

\section{Cerone on Lassus}

Cerone highlights Orlande Lassus, or Orlando di Lassus as Cerone prefers, and Giovanni da Palestrina as the major composers of the late $16^{\text {th }}$ century. Cerone notes that Lassus composes as the occasion demands and varies his style according to the needs of the text. In addition, his secular music can be performed vocally or instrumentally.

Orlando di Lassus is very different from the composers so far mentioned, for he has written in all the types of music discussed. He varies his style according to the occasion-sometimes writing works which are grave and full of majesty, at other times writing those that are sweet, graceful, and harmonious. He sometimes writes in a sad, tearful manner, while on other occasions his works are light and happy. Often his works are appropriate for any kind of instrument, whether keyboard or wind. ${ }^{45}$

Lassus served Ferante Gonzaga of Mantua and accompanied him to Sicily and Milan during the years 1546-9. He also toured Naples from about 1550 to 1553 with his patron, Constatino Castrioto. During his later tenure at the court of Albrecht V of Bavaria, he returned to Italy in the period of 1574 to 1579 . In addition to his Italian trips, Lassus' compositions, many of which are on Italian texts, were widely published in Italy by the time of his death in 1594 .

\section{Cerone on Palestrina}

Cerone deems Palestrina the most important composer:

But above all these (in church music) one ought to follow the steps of Pietro Luigi Palestrina, and imitate his compositions as much as possible, for in my humble judgment, his style is the best or one of the best. It is harmonious, sweet, grave, happy, learned, most observant of the rules and regulations of any music yet to be heard in the world thus far. With much reason, one can speak of him as "Daphnis, most worthy of the shepherds." We admire his ability and hold him as a great authority... But again I say with considerable truth that he has become the light of music, the source of various compositions, the model of good rules, the honor and crown of Italian musicians. ${ }^{46}$

45. Orlando de Lassus à sido muy differente de todos los nombrados hasta aqui, pues tiene compuesto en todas las sobredichas maneras: digo, sin tener siempre vn mesmo estilo, mas variandole à sus occasiones segun se hallaua de venia, que le combiaua à componer vnas vezes graue, deuoto, y con magestad: otras vezes dulce, suaue, y harmonioso; quando triste y lloroso, y quando ayroso y alegre: mas siempre en posiciones muy apropriadas para las poder concertar con qualquiera genero de instrumento, de toque ò soplo que sean. p. 90.

46. Pero sobre todos estos (en lo Eccl.) hanse de seguir las pisadas de Pedro Luys Prenestina, y imitar sus composiciones quanto mas fuere possible, que (à mi poco juyzio) su estilo es ò el mejor ò vnos de los mejores, mas 


\section{Palestrina's life was well known to Palestrina:}

With his music, I say, he has eclipsed the fame of those past, astonished the present, and left a perpetual memory of himself to those who will come after him. His two sons, Angelo and Sylla, will try to follow the same path, imitating the divine genius and singular ability of their father, as part of their heredity... He has made many disciples, who can be called his sons... Suffice it to say that although you are dead, you live, and I say that you will never die in the memory of mortals. ${ }^{47}$

\section{Certain of Palestrina's earlier works serve as excellent models:}

Among his works let them consider particularly the first book of motets for five voices, the first masses for four voices, the first motets for five voices, the songs to the Virgins (Magnificats), the Missa L'homme Armé, and the music for the Cantica (the Song of Songs), that is the fifth book of motets for five voices, where one will see things to wonder at and admire, and where he has opened the door to his shop and shown the rich silks and brocades of his excellence and singularity. ${ }^{48}$

But Palestrina also continues previous traditions, as in his use of the celebrated L'homme Armé melody. Chapter 59 includes a lengthy discussion of Palestrina's Missa L'homme Armé (1570), notable for its use of proportions. In this chapter, Cerone offers a detailed analysis of this Mass and presents a system for others to follow in their consideration of this master composer.

... and there is something to please one or the other, as we see Palestrina has done in his Missa L'homme Armé, on a very old subject, found by Busnois (as Petro Aron writes in the Chapter 38 of the first book of his Toscanello). The first to use this subject was a contemporary of his and the teacher of Josquin, Ockeghem. Afterwards, his student wished to make a point by composing two masses on this subject: Missa L'homme Armé Sexti Tone and the Missa L'homme Armé super Voces Musicales. ${ }^{49}$

harmonioso, suaue, graue, deuoto, llano, alegre, docto y mas obseruado de reglas y terminos musicales, $\overline{\mathrm{q}}$ à auido hasta oydia en el mundo: y con mucha razon se puede dezir del: Daphnis inter pastores primus: admirandonos de su habilidad y teniendole en grandissima authoridad... Puedo dezir otra vez con mucha verdad, que el à sido la luz de la Musica, la fuente de las varias cõposiciones, la muestra de las buenas reglas, la guia de las verdaderas obseruaciones, la mina de las muchas y differentes obras, la honra y corona de los Musicos de Italia. p. 90.

47. Con su Musica, digo, eclypsò la fama de los passados, espantò los presentes y dexò de si perpetua memoria à los venidores: donde tambien procuran dos hijos suyos Angelo y Sylla, seguir este camino; imitando al diuin ingenio y à la singular habilidad de su padre, como cosa suya hereditaria... Tiene hecho muchos dicipulos, que pueden llamarse hijos suyos... Basta dezir, que aunque soys muerto, viuis; y que digo soys de nunca morir en la memoria de los mortales. pp. 90 91 .

48. Entre todas sus obras consideren particularmente los primeros motetes y las primeras Missas à cinco y las primeras Missas à quatro bozes (aunq sean muy aduados) los primeros motetes à cinco. las Virgines, la Mess. Lommearme, y la Musica $\bar{q}$ hizo sobre la Cantica, $\bar{q}$ es el quinto lib. de sus motetes à cinco bozes, donde vedran cosas para mirar y admirar; $\mathrm{y}$ donde el abriò la puerta de su tienda, y mostrò las ricas sedas y brocadas de su eccelencia y singularidad. p. 90 .

49. ..y que el vno por el otro haya de deleytar: como vemos auer hecho Prenestina en su Missa del Lomme armè: subiecto muy antiguo, hallado (porquanto escruie D. Pedro Aron en el Cap. 38 del prim. Lib. del Toscanello) de Busnoys; sobre del qual, el primero que compusiesse Missa, fue vn contemporaneo suyo y Maestro de Iusquin, llamado Ocheghem (sic), despues su discipulo se quiso señalar en hazer dos dellas, la vna intitulada, Missa Lomme armè Sexti toni; y la otra Missa Lomme armè Super voces musicales. p. 756. 
Cerone notes that Morales also composed a mass on this melody, but that Palestrina culminated the tradition with his second mass on the melody (1582), written in a more modern manner because of its greater use of pervasive imitation.

Finally, our singular Palestrina has composed another in a more modern style, which is published in his third book of masses. ${ }^{50}$

Cerone was hardly the first to identify the preeminence of Palestrina, though he played a major role in the continuing veneration Palestrina was to receive. We have already seen that Montanos emphasized Palestrina's importance as early as 1592. Lodovico Zacconi singled out Palestrina as a perfect model in the second part of Prattica di Musica (1622), reflecting the views of the first part of this treatise published in 1592 and reprinted in 1596. ${ }^{51}$ As Klaus Fischer has recently pointed out, Italian theorists considered Palestrina the model composer of the late Renaissance even before his death. Vincenzo Galilei praised Palestrina's expressivity in Fronimo (1568), and Pietro Pontio, a theorist that Cerone often paraphrased, placed Palestrina on the same level as Jachet de Mantua, Adrian Willlaert, Nicolas Gombert, and Cipriano de Rore in his Ragonamiento di Musica (1588). Pontio praised Palestrina even more effusively in the Dialogo (1595).

But ultimately, Cerone's analysis of Palestrina is of the greatest importance. Recently Michael Zywietz has written: "The systematic codification of the compositional procedures derived from the work of Palestrina is actually Cerone's accomplishment."52

\section{Cerone's Principal Views on Music's History}

In summary, Cerone provides his readers with a comprehensive, if derived, overview of the music and theory of his day; but he is also is at pains to give a historical context, of which the following are the principal points:

- Music had its origins in nature.

- There is disagreement about the inventors of music.

- It is possible to find specific dates for the origins of each musical instrument.

- There is a distinction between ancient music (monodic) and our music (polyphonic).

50. Finalmente el nuestro singular Prenestina, tiene compuesto otra con estilo mas moderno; la qual và impressa entre las Missas del iij. Libro... p. 756.

51. James Haar, "A Sixteenth-Century Attempt at Music Criticism," Journal of the American Musicological Society 36 (1983): 191-209. Palestrina was probably known to Zacconi only through reputation, while Lassus seems to have been a personal friend. p. 196.

52. "Die systematische Kodifizierung der vom Werk Palestrinas abgenommenem Satzregeln ist wesentlich das Werk Cerones." Michael Zywietz, "Cerone" in Die Musik in Geschichte und Gegenwart, Personenteil, vol, 4, col. 574. 
- "Ancient" music beings with Josquin.

- Boethius was the most important theorist.

- The history of polyphony began before Guido of Arezzo.

- Morales influenced Ortiz and other Spanish masters.

- Phinot influenced many subsequent composers because of his elegant style.

- Lassus was a model composer notable for the diversity of his styles.

- Palestrina was the most important composer of his time.

\section{A Comparison with Scipione Cerreto}

As has been suggested above, Cerone was part of a thriving intellectual and artistic tradition in Naples. Furthermore, during Cerone's lifetime, there were two other major theorists working in Naples: Rocco Rodio and Scipione Cerreto. Rocco Rodio was born in Bari around 1535 (there has been some controversy about the place of his birth) and died in Naples after 1615. Rodio worked in Naples during his mature career where he was part of the innovative school of composers, including Gesualdo, who were interested in chromatic experiments. His Regole di Musica (1600) reflects his audacious approach and contrasts with the conservatism of $E l$ Melopeo. On the other hand, Scipione Cerreto (c. 1551-c. 1633) was, like Cerone, conservative. Cerreto's Della Prattica Musicale (1601) provides valuable insights into the Neapolitan musical life of the $16^{\text {th }}$ century. In addition, Cerreto, writing in Italian, is precise, didactic, and covers all the essential of a musical education. Curiously, neither Cerone nor Cerreto, although living in Naples at the same time, mention each other in their treatises.

In a chapter entitled "Nonni di I Musici Napolitani e Compatrioti, che sono stati in questa Città di Napoli dall' Anno 1500, infino al di d'oggi," Cerreto lists the major Neapolitan composers and performers of the $16^{\text {th }}$ century, distinguishing between living and dead masters. Instrumentalists, furthermore, are divided according to which instrument they performed. ${ }^{53}$ The significance of 1500 is considerable, for Cerreto surveyed a hundred years of music making. But 1500 also marks the beginning of the late Renaissance's clearer conception of the composer and performer as an individual creator. ${ }^{54}$ Although these two theorists radically differ from each other

53. Cerreto is discussed in Sir John Hawkins's A General History of the Science and Practice of Music (1776): "This, though it appears to be an elaborate work, and promises great instruction to such as delight in music, contains little more respecting the science than is to be found in Boethius, Franchinus, Zarlino, Zaccone, and others of the Italian writers." p. 447.

54. Rob C. Wegman, "From Maker to Composer: Improvisation to Musical Authorship in the Low Countries, 14501500," Journal of the American Musicological Society 49 (1996): 409-79. Wegman notes that by 1500 there was a greater emphasis on personal style, historical awareness, and the role of the composer as an individual creator. 
in methodology and purpose, they both exemplify the intellectual energy present in Naples at the end of the $16^{\text {th }}$ century.

\section{Cerone's Historical Reputation}

The conservative and didactic tone of El Melopeo not only insured its acceptance but also reflected the tenets of the Counter-Reformation. Thus El Melopeo became the ideal treatise for subsequent musical education and theoretic discourse throughout the Hispanic Empire at a time when orthodoxy was stoutly maintained.

Cerone, however, was quickly and widely read, outside Spain. For example, Marin Mersenne, in the second volume of the French edition of the Harmonie Universelle (1636), mentions Cerone in the same breath as Zarlino and Vincentino, the most august theorists of the Italian Renaissance. ${ }^{55}$ As suggested earlier, Cerone's conception of a multi-volume treatise that included both theoretic and practical aspects of music impacted developments in music theory outside the Hispanic Empire from Mersenne through Athanasius Kircher's Musurgia Universalis (1650). Thus, although Cerone was considered a conservative writer in the Hispanic world, he may have contributed to the more liberal thinking that dominated scientific musical treatises in other parts of Europe.

Subsequent Spanish theorists through the early $18^{\text {th }}$ century (or the period of Padre Antonio Soler) were influenced by Cerone's conservative orthodoxy. For example, André Lorente's El Porqué de la Música (1672) frequently cites Cerone as a major authority and is largely derived from $\mathrm{El} \mathrm{Melopeo.} \mathrm{In} \mathrm{the} \mathrm{opening} \mathrm{chapter,} \mathrm{Lorente} \mathrm{mentions} \mathrm{authors} \mathrm{whose} \mathrm{work} \mathrm{he} \mathrm{admires:}$

Various other authors give differing definitions of music. I do not need to cite all of them, for the following are the most essential: Pedro Cerone, Juan Bermudo, and Francisco Montanos in their books on music. ${ }^{56}$

Cerone is later cited as the source for the correct understanding of the beginnings of mensural notation. Lorente cites a passage included earlier in this article:

The ancients had a different type of notation that they used in music. I do not place them here for they are not now useful. The eight figures that we now use were invented by the Frenchman Jean de Muris in the year 1352, as the curious can read in Don Pedro Cerone. ${ }^{57}$

55. Mais puis que ce n'est pas mon dessein de copier Zarlino, du quel du Caurroy, \& tous les autres, mediatement, ou immediatement, ont puisé tout ce qu'ils sçauent de pratique; \& que Nicolas Vincentin \& Cerone, ont donné quantité... p. 85.

56. Otras muchas Difiniciones dàn diferentes Authores de la Musica, no me detengo en referirlas, por parecerme suficientes las que dexamos puestas; el que necessita de ellas, vea à D. Pedro Zerone (sic), al Padre Fr. Iuan y à Francisco Montanos, en sus Libros de Musica, que alii las hallara \& alii multi. p. 2.

57. Los antiguos tenian otro genero de Figuras con que se entienden en la Musica; no las pongo por no ser de utilidad en estos tiempos: estas ocho Figuras q oy tenemos, y usamos, las inventò Iuan de Muris Frances, el Año de 1352, como lo podrà ver el curioso en Don Pedro Zerone (sic). p. 146. 
Almonte Howell sums up Lorente's dependence on Cerone, “... much of the musica speculativa complete with erudite references and marginal notes, and a good deal of the musica practica as well were cribbed word for word from the inexhaustible author of El melopeo $y$ Maestro." 58

As suggested above, Cerone's influence continues into the $18^{\text {th }}$ century. Padre Pablo de Nassarre's Escuela de Música (Zaragoza, 1724) is thus closely modeled on El Melopeo. Nassarre emphasizes Gregorian chant, Renaissance notation, and classical authorities. The opening chapter, which outlines music's origins, reflects Cerone's presentation of this subject. Later and dramatically, Padre Antonio Soler's Llave de la modulación y antiguedades de la música (Madrid, 1762) likewise adopts Cerone's methodology and outlooks, including Cerone's interest in canonic artifice; but Soler evidences an even stronger historical approach, as can be gathered from the treatise's title.

Cerone deeply influenced the musical thinking of Nueva España during the colonial period. Robert Stevenson notes, "The earliest still surviving treatise brought to the New World in colonial times happens to be precisely El melopeo." ${ }^{59}$ Thus El Melopeo was also read by Sor Juana Inés de la Cruz, the greatest Mexican intellectual of the later $17^{\text {th }}$ century. Sor Juana's copy of El Melopeo was carefully annotated, indicating that she both understood and critiqued its contents. She particularly studied chapter 53, whose comments on Pythagorean tuning fascinated her and served as a springboard to her own theories. Professor Stevenson writes:

Shown her pathway by López Capillas-the sole maestro de capilla whose works Sor Juana may personally have heard in Mexico City before reciting final vows February 24, 1669 -she obtained her own personal copy of El Melopeo y maestro- a copy minus a few pages still survived in 1988 at the Biblioteca del Congreso in Mexico City. Her volume encountered by bookseller Demetrio García in 1930 (together with her autographed copy of Octavio della Mirandola's anthology of Latin poets) contains her own handwritten comment at the bottom of Cerone's page 284, continued at the top of 285-where she signs herself "Esta Raçon de Ceron su discipula Juana Inés de la Cruz." 60

As Stevenson notes, Sor Juana by 1676 was in command of Cerone's complex vocabulary and thought process (she perhaps read Cerone with greater comprehension than any reader before or since). Cerone's ideas furthermore influenced the "Respuesta a Sor Filotea de la Cruz." In addition, it seems that her lost musical treatise Caracol, cited in her Romance 21 "Depués de estimar mi amor," likewise drew upon Cerone. ${ }^{61}$ (1972): 64 .

58. Almonte Howell, "Symposium on Seventeenth-Century Music Theory: Spain," Journal of Music Theory 16

59. Robert Stevenson, review of "Pedro Cerone, El Melopeo Tractado de Musica Theorica y Practica. Facsimile reproduction in two volumes of El melopeo y Maestro. Introduction by F. Alberto Galleo. Bologna: Forni, 1969," American Musicological Society Journal 24 (1971): 482.

60. Robert Stevenson, "Sor Juana Inés de la Cruz's Musical Rapports: A Tercentenary Remembrance", InterAmerican Music Review 1 (1996): 1.

61. Mario A. Ortiz "El Discurso Especulativo Musical de Sor Juana Ines de la Cruz" unpublished paper, Indiana University, no date, 1-2. 
The turning point of Cerone's reputation occurred during the later $18^{\text {th }}$ century. The reign of Carlos III (1759-88) was marked by the increasing influence of French rationalism and a consequent reevaulation of received doctrine. Carlos III came to the throne after the Seven Years' War (1756-63), and it was during his reign that the Jesuits were expelled (1767). The political and cultural climate changed dramatically during these years and Cerone suffered as a consequence.

Antonio Eximeno y Pujades (1729-1808), the Spanish Jesuit turned theorist and novelist, reflecting this more liberal atmosphere, criticized Cerone savagely. Eximeno lived in Rome after the explusion of the Jesuits from the Hispanic Empire in 1767, where he conceived and wrote Don Lazarillo Vizcardi (1806). A musical takeoff on Don Quixote (1605), Don Lazarillo portrays Cerone as a conservative fanatic given to every kind of bizarre excess. Eximeno's earlier Dell' origine e della regole della musica, colla storia del suo progesso, decadenza, e rinnovazione (1774) sets the stage by arguing for the naturalness of music. Eximeno and Padre Martini (who includes Cerone among the theorists he valued) came into conflict because of Eximeno's condemnation of intricate polyphony. But Eximeno's colorful novel perpetuated Cerone's name and ideas, even though these are usually distorted. Eximeno read El Melopeo carefully and probably with the considerable degree of respect accorded a formidable adversary. It is hard to tell how directly Eximeno influenced later views regarding Cerone, but one suspects that Spanish writers up until recently were influenced by him. Eximeno's dim estimation of Cerone sadly continued into the $19^{\text {th }}$ and $20^{\text {th }}$ centuries in other countries as well (particularly France thanks to Fétis), as Robert Stevenson and others have noted. ${ }^{62}$

\section{Conclusion}

At the outset of this article, I referred to Warren Dwight Allen's Philosophies of Music History, which notes that Seth Calvisius' De origine et progessu musices (1600), the supplement to the Compendium Musicae Practicae (1594), was the first source to attempt a history of music. ${ }^{63}$ Calvisius treatises were published well before El Melopeo, and the two authors were certainly unaware of each other. Calvisius viewed music from the Lutheran stanpoint, while Cerone emphasized a devout Catholic, Counter-Reformation approach. As Allen notes, Joseph Justus Scaliger's De Emendatione Temporum (1583) impacted Calvisius deeply, providing a model for several of Calvisius' writings. Cerone did not have the advantage of such a model. However, despite manifest differences, the two authors shared an interest in the origins of music and an awareness that it has natural as well as divine sources. While Allen is correct in heralding Calvisius as the first "music historian," Cerone surprisingly shared many of Calvisius' views.

62. Stevenson, review, 480 .

63. Allen, op. cit., 5-6. 
In conclusion, El Melopeo required long research and intense planning. Throughout this treatise quasi-historical statements are combined with pedagogy and moralising. Cerone's reliance on other authorities is abundantly clear, and his emphasis on traditional views of music's origins and development is unwavering. It is when Cerone becomes personal that he is most interesting and most valuable (such as his reflection on the life of Palestrina). Although Cerone is hardly a historian in the later sense of the term, we must be grateful for this pious and frequently charming priest's passion for collecting, cataloguing, and perspicacious commentaries. 